\title{
材料系学協会の戦略活動と今後の研究展望* \\ Current Movements on the Cooperation of Materials Societies in Japan
}

\section{佐久間健人 ${ }^{* *}$ \\ Taketo SAKUMA}

Key words materials, nanotechnology, academic society, education, research, university, SCJ

\section{1.はじめに}

「材料の学」という言葉を聞いて私がまず考えたのは, 1950 年代に成立したマテリアルサイエンス〜材料科学と いう学問分野を再構築しようという試みではという期待感 であった。実態は, 私の認識とはややズレているようであ るが，私が理解している最近の材料系学協会の動きを紹介 しながら，材料研究の今後の進め方を議論する参考に供し たい.

\section{2. マテリアルサイエンスの位置づけ}

マテリアルサイエンスという学問は, 完成してからまだ 50 年程度しか経っていない新しい分野である。見方によ っては，古くからある種々の学問分野の谷間に位置してい るといえる。例えば，それを理学という観点から見ると， 物理, 化学, 生物学という学問体系の恩恵を受けながら, これらの分野の境界領域に生まれてきたのである。一方， 工学的なセンスで見ると, 電気, 機械, 土木・建築といっ た古くからある学問分野の基盤を支える学問分野であると いえる（図 1)。ある識者の表現を借りれば，マテリアル サイエンスは種々の工学分野を支える縁の下の力持ちとい う立場にあるといえる。縁の下の地位にあるがゆえに、、 テリアルサイエンスあるいは材料系学科は, 現状では, 工 学の中で人気のある学科とはいえない.しかし，このこと はマテリアルサイエンスという学問分野に魅力がそしいと いうことを意味しているのではない.

例えば，マテリアルサイエンスという学科が工学ではな く理学の中に存在している大学がある. 私が二十数年前に

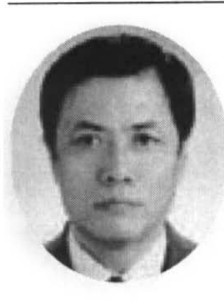

*原稿受付 平成 17 年 6 月 3 日

**(独) 大学評価・学位授与機構（東京都小平市学 園西町 1-29-1)

佐久間健人

昭和 45 年 3 月, 東北大学大学院工学研究科博士 課程修了（工学博士）。

研究分野：材料科学 (金属およぴセラミックス の組織制御, 高温力学特性など).

著書：材料科学概論，朝倉書店 $(2000)$, 七ラミ ック材料学, 海文堂 (1991) など.
ケンブリッジに滞在していたときの経験であるが，この大 学の Material Science Departmentは, Natural Science コー スの中の 1 学科であった. 当時, ケンブリッジ大学の Natural Science コースに所属する女子学生の比率は約 $15 \%$ あったた。このコースの中から, 専門課程として Material Science Department に進学してくる学生には優秀 な学生がたくさん抢り，しかも女子学生の比率が高いこと が特徵であった。 1982 年の Material Science Department の女子学生の割合は打よそ $40 \%$ に達しており, 学科の教 員が驚いていたほどである. 女子学生の比率の高さを別に すれば, '状況はオックスフォード大学でも同じである。し かしイギリスの他の多くの大学では Material Science ある いは Metallurgy という学科は工学部の中にあり，そこで は苦戦を強いられている. 俗に「赤煉瓦大学」と呼ばれる シェフィールド, マンチェスターなどの由緒ある大学の教 員から，マテリアルサイエンス分野に優秀な学生を集める のは大変だという話を何度となく聞いている。

この状況は, タイのチュラロンコン大学でも同じである. この大学の Material Science Department は理学部の中にあ り, Metallurgy という学科は工学部に所属している。この 大学の卒業生で, 東大に留学していた数名の研究者の話に よると, 理学部の Material Science 学科は, 女子学生が非 常に多く, 人気学科のひとつだそうである.これに対して, 工学部の Metallurgy 学科は, 女性がほとんどいなくて, 人 気学科とはいえないという状況である。 大学の学科の人気 が, 学問的な興味だけではなく, 多くの要因に依存してい ることを示す一例である。

また，工業材料という観点で見ると，材料は金属，七ラ ミックス, 高分子という三大材料に分類される. Material

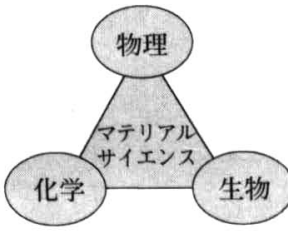

理学的

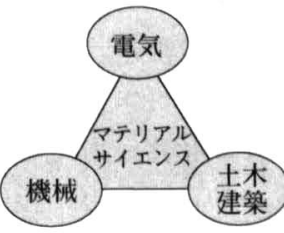

工学的

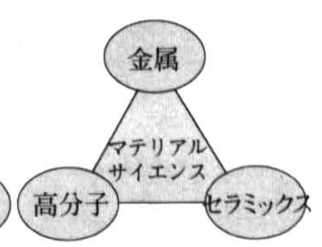

工業材料
园1 MEMSの製品の位置づけ 


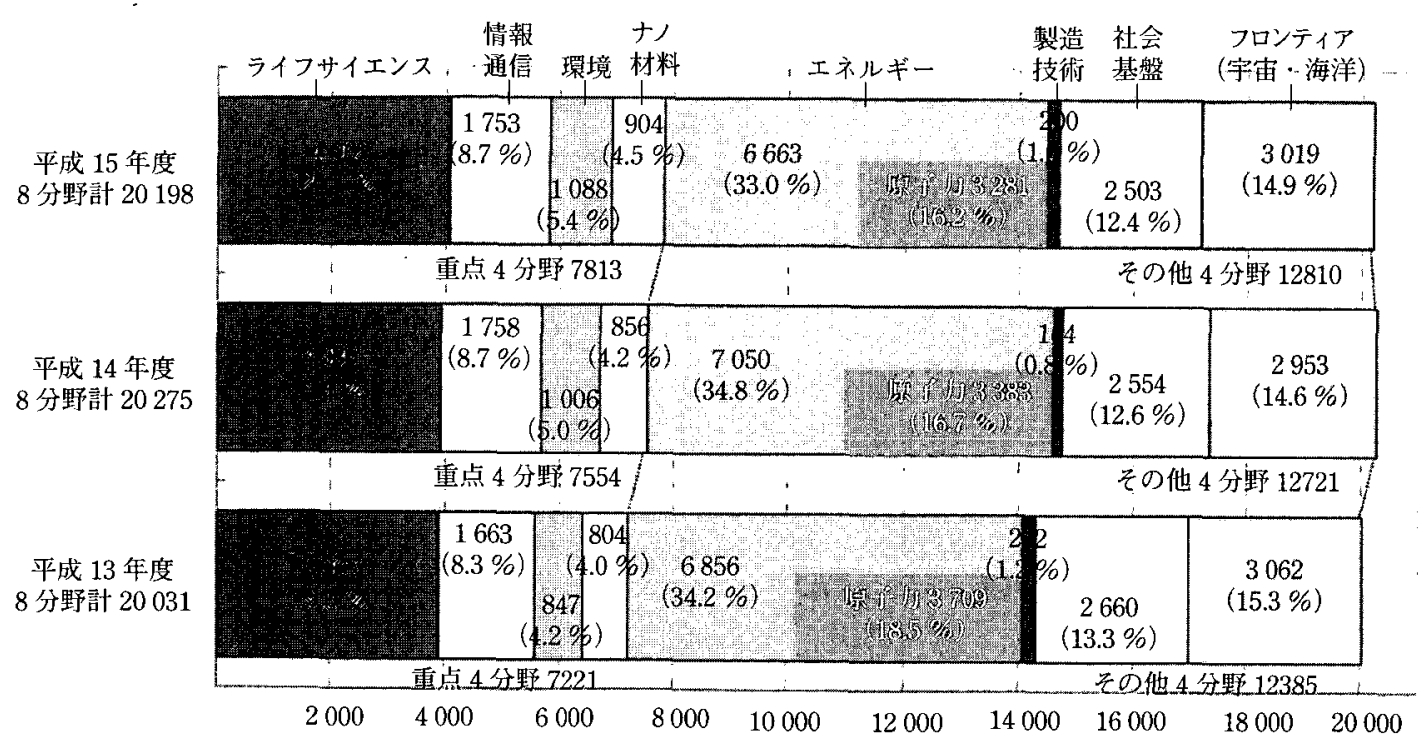

（注）1. 本資料は各府省から提出されたデータを基に集計したものである.

2. 上記科学技術関係予算には大学に係る予算（国立大学の附置研究所捛よび大学共同利用機関を除く），分野横断 的に実施される施策事業等，研究分野に分類されていないもの合計約 1 兆 5000 億円は含まれていない.

3. 原子力の予算額については, ライフサイエンス分野のものも一部含む.

図 2 科学技術関係予算（大学予算を除く）の8 分野の予算額推移 総合科学技術会議資料 (平成 15 年 5 月 27 日)

Scienceの分野は，これらの材料を包括する学問分野であ る. 実際に,この名称にふさわしい学科か㳄米の大学では かなり前から教育と研究に取り組んでいる。しかし我国の 大学に招ける過去の材料系学科の実情は, これとはかなり 異なっている. 日本の大学の工学部でなされてきた材料学 教育は，金属系とセラミックスおよび高分子系で異なった 学科群でなされてきたといえる.このことが, 日本の材料 系学協会活動にも影響を及ぼしている，本稿では，このよ うな材料にかかわる教有と研究の実情を紹介するととも に, 材料柔学協会の最近の動きから今後の材料系の活動の あり方についての私見を述べる。

本稿が,「材料の学」という新しい概念を提唱している 方々の今後の活動の一助となれば幸いである.

\section{3. 第 2 期科学技術基本計画と材料研究}

第 2 期科学技術基本計画の重点 4 分野の中にナノテク， ロジー・材料という分野が書き込まれたこともあって, 我 国の材料研究はそのメリットを享受している。元して，そ の状況を今後も継続し，材料科学分野の国際的な優位性を 維持していくことに期待している人達が多い. 今後の材料 系の学協会活動を進めるにあたって，この点を考慮に入れ ておく必要があろう。

第 2 期科学技術基本計画では，重点化に指定された 4 分 野（ライフサイエンス，情報通信，環境，ナノテク・材料） に加えて，4つの重要分野（エネルギー，製造技術，社会 基盤，フロンティア）が指定されている，蛇足ながら付け 加えると，これら 8 つの重点分野に投下されている研究費 は大きく異なっている。総合科学技術会議の資料には，平 成 13 年度から 15 年度までの科学技術関係の予算がどのよ
うに変わってきたか, 8 分野でまとめたものがある（図 2). これを見ると，ライフサイエンスの予算は約 $20 \%$ ，情報 通信が約 $8 \%$, 環境が $5 \%$ 強なのに対し，ナノテク・材料 は $4 \%$ である．その他の重要分野の中でも予算投下額は巽 なり，例えばエネルギーは $30 \%$ をはるかに超える予算が 投下されているのに対し，製造技術は $1 \%$ 程度に過ぎな い.この結果には，日本の財政構造のシステムに関わる 構造的な要因が反映されているものと思われる。しかし， 「材料の学」で目指しているような機械と材料の境界領域 から見ると，製造技術に関して，将来の日本の産業の育 成に資するようなより魅力的な提案をしていく努力が必 要であることが痛感される．個人的な見解であるが，「材 料の学」の取り組みが，製造技術を活性化するという立 場を支援するものであってほしいと期待するものである。

\section{4. ナノテクノロジーと材料研究}

次に，近年注目を集めているナノテクノロジーと材料研 究との関連を見てゆくことにする。图 3 は，2001年のナ ノテクノロジーに関する三菱総研の資料加ら打借りしてき たものである。縦軸拉よび横軸はアメリカに対する日本の 科学競争力および技術競争力をとったものである。ここに 取り上げられている技術は, 光触蝶，マイクロマシン，量 子細線, 量子ドットなど我々が最近よく耳にするテーマで あり, 従来の産業構造に関わるクラシカルな材料学のテー マは取り上げられていない。しかし，ナノテクノロジーの 競争力に関するこの資料は, 日本の材料科学の実情の一端 を示しているように思える.

図 3 は, ナノテクノロジーを科学競争力から見ると，日 本が優位に立っているものはごく一部であり，一方，技術 


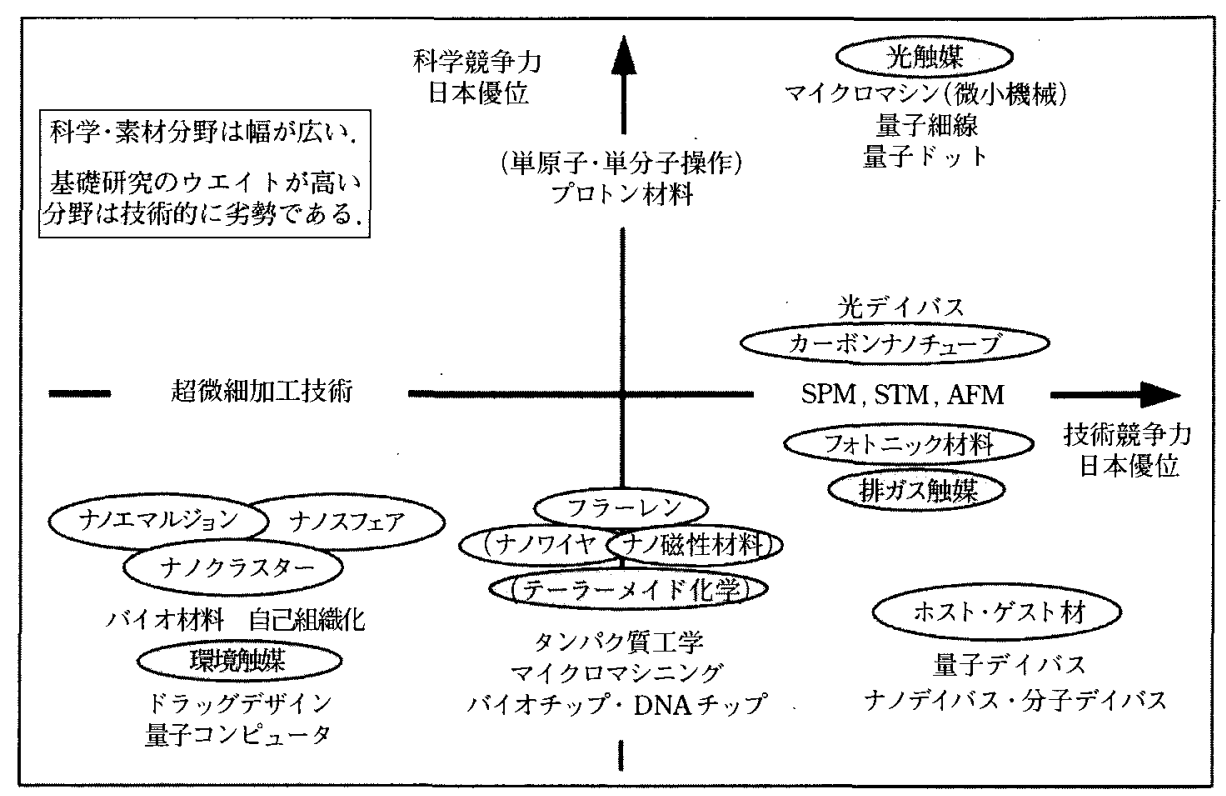

国 3 日米のナノテクノロジー科学・技術競争力マップ (全体図)

(株) 三菱総合研究所調查報告書（2001 年 3 月 30 日）

表 1 全国大学材料関係教室協議会の学科名

\begin{tabular}{|c|c|c|}
\hline & 1974 年 4 月 & 2002 年 9 月 \\
\hline 北海道大学 & 金属工学 & 物質工学 \\
\hline 東北大学 & $\begin{array}{c}\text { 金属工学, 金属材料 } \\
\text { 工学, 金属加工学 }\end{array}$ & $\begin{array}{l}\text { 金属工学, 材料物性学, } \\
\text { 料加工プロセス工学 }\end{array}$ \\
\hline 東京大学 & 治金学 & マテリアル工学 \\
\hline 東京工業大学 & 金属工学 & 材料工学 \\
\hline 名古屋大学 & 金属工学, 鉄鋼学 & $\begin{array}{c}\text { 材料機能工学, } \\
\text { 材料プロセス工学 }\end{array}$ \\
\hline 京都大学 & 治金学，金属加工学 & 材料工学 \\
\hline 大阪大学 & $\begin{array}{c}\text { 治金 ·金属材料学, } \\
\text { 溶接工学 }\end{array}$ & $\begin{array}{l}\text { マテリアル応用工学, マ } \\
\text { テリアル科学, 知能・機 } \\
\text { 能創成工学, 生産科学 }\end{array}$ \\
\hline 九州大学 & 治金工学，鉄鋼治金学 & 材料工学 \\
\hline 早稲田大学 & 金属工学 & 物質開発工学 \\
\hline
\end{tabular}

競争力では優位に立っているものが多いことを示してい る.このことは，ナノテクをはじめとする多くの学問分野 で，日本発の学問体系というものが出てきていないことを 示しているように思われる。この論は，そのまま材料科学 分野にもあてはまる、材料科学は，諸外国に比べて日本が 優位性を維持している分野のひとつであることが様々な資 料に述べられている，しかし，材料科学という学問分野自 体が欧米発であり，日本から出発したものではない，後述 するように，大学に拈ける材料科学あるいは材料系の教育 と研究，あるいはそれと密接に関連する国内の学協会活動 が，欧米の大学と遜色のないバランスの取れたものである とはいえない形で発展してきたという経緯がある.現在は， 多くの関係者の努力によって，このバランスを調整するた めの様々な取り組みがなされているのは，ここら辺の事情 によっている。

付言しておくならば，ナノテクノロジーと材料は，以前 から同一分野として括られていた研究領域ではない. 2000 年 1 月に出された Clinton Initiative の影響で，科学技術政 策の文書の中に突然埋め込まれたものである。このことは，
ナノテクノロジー・材料を括るような新しい学問体系の構 築が可能であるかもしれないという期待感を持たせるもの である。この新しい学問分野が日本から発せられるのであ れば，国際社会に対する大きなインパクトを与えるものと なるであろう。「材料の学」に対する取り組みには，この 観点での貢献に寄与するであろう。

\section{5. 日本の大学における材料の教育・研究の特徴}

日本の大学では, 材料系の教育と研究は, 材料科学という 観点でなされはじめたわけではない.むしろ, 当初は金属と ほかの材料とが工学部（あるいは理工学部）の異なる学科 でなされていた，金属に関する教育・研究が，金属系学科で なされてきたのに対し，無機材料や有機材料は，多くの場合， 応用化学などの学科内でなされてきたという経緯がある。

1982 年に全国の大学の中の学科名称の数を調べたこと があるが，そのとさは金属系の学科の数は 26 大学 36 学科 であった．それに対して，セラミックスあるいは無機材料工 学科と名乗った学科は 3 つ.すなわち，材料系の学科が金 属系に偏っていたといえる，かなり以前から，全国の金属 系教室の教育・研究内容が金属にとどまらず，セラミック ス, そして高分子へと広がりつつあり，学科名称変更が相 次いでいるのはこのような事情が背景にあるためである。

具体的に改組の事例を紹介する. 全国大学材料関係教室 協議会という組織の名簿から一部を抜き出してまとめたも のが表 1 である. 1974 年, 今から 30 年ほど前には, ここ に示したすべての大学に金属工学, 治金学, 鉄鋼学, 溶接 工学と, 今から見るとクラシカルな名称の学科が並んでい る.ところがこれを 2002 年の時点で見ると, 実に様々な 名前に変わっている. 金属という名称は, 複数の材料系学 科もしくは専政を有しているグループの中の一学科として 残っているに過ぎない。 


\section{金属工学研究連絡委員会 (38989)}

日本金属学会 (8568)，日本塑性加工学会 (4126)，日本鉄鋼協会 (9490)，日本鋳造工学会 (3117)，溶接学会 (3802)，高温学会 (784) 軽金属学会 (2222)，日本熱処理技術協会 (923)；日本非破壞検呇協 会（2531），日本防錆技術協会（543），表面技術協会（2883）

\section{材料工学研究連絡委員会 (60118)}

安全工学協会 (533), 火薬学会 (797), 高分子学会 (10485), 色材 学会 (1900), 触媒学会 (2344), 石油学会 (4418), 繊維学会 (2094), 炭素材料学会 (992), 電気化学会 (2991), 日本印刷学会 (1209), 日本エネルギー学会 (1223), 日本ゴム学会 (2369), 日本材料科学 会 (516)，日本材料学会 (3029)，日本材料強度学会 (519), 日本写 真学会（1056），日本セラミックス協会（5164），日本デザイン学会 (2066)，日本塗装技術協会 (505)，日本バイオマテリアル学会 (977)， 日本複合材料学会 (713), 日本膜学会 (556), 日本油化学会 (2014), 日本溶射協会 (565)，日本レオロジー学会 (936)，腐食防食協会 (1573)，プラスチック成形加工学会 $(680)$ ，粉体工学会 (674)，粉 体粉末治金協会 (1341)，無機マテリアル学会 (1001)，有機合成化 学協会 (4878)

图 4 日本学術会議第 5 部（第 18 期） 金属工学研究連絡委員会および 材料工学研究連絡委員会に所属する学会

では学協会はどうだろうか.日本の学会べースで見ると， 事情は異なっている. 図 4 は第 18 期の日本学術会議の第 5 部 (工学) の資料から抜粋したものである。第 5 部の中 には, 金属工学研究連絡委員会 (金研連) と材料工学研究 連絡委員会（材研連）の2つの研連がある，学問という立 場で考えると，これはあまりバランスの良いものではない。 しかし，これは日本の大学における材料教育が, 先に挙げ たように金属グループとセラミックス，高分子のグループ が別々の学科でなされてきたことによっている.

第 18 期で見ると, 金研連には 11 の学協会がある。これ らの学協会は, 金研連を第一順位として登録した学会であ る. 11 学会で会員総数 3 万 8900 名である. それに対して, 材研連には 31 学会が所属し, 会員の総数は 6 万名を超え ている. 両者の研連に, 第 2 順位もしくは第 3 順位までに 登録している学会の会員数をまとめると, 金研連関係の研 究者数は約 5 万名強, 材研連の会員総数は的 10 万名とな っている。

このように，材料研究に関わる研究者の総数は多いが, 単一学会で会貴数 1 万人を越えているのは高分子学会だけ であり，次いで鉄鋼学会の約 9000 人，金属学会の約 8 000 人である。これは，第 18 期の統計であり，その後の 会員数はこれより減少しているところが多いと推察され る.すなわち，単一の材料名を冠した日本の学協会として は，1万人という会員数を確保するのがやっとであるとい うのが現状である。

このような状況に危機感を抱いて, 第 18 期の学術会議 の第 5 部内に時限の「社会・産業と材料」研究連絡委員会 が設置され，材料横断的な報告書がまとめられた。これは， 材研連の委員長だった安部明廣会員を中心としてまとめら れたものであり，平成 15 年 3 月 17 日付で，「物質・材料
研究開発に関わる国家戦略確立の必要性について」と題し て，同研連より報告されている，これは恐らく日本の中で 高分子, セラミックス, 金属に関係する研究者が共同して 出した報告書として初めてのものであろう。この種の取り 組みが今後も継続的に続けられ, 我国の材料に関わる教 育・研究が健全に発展し, 材料科学の国際的な優位性が維 持されることを期待したい.

それでは, 欧米の学協会はどうなのか，2，3の例を取 り上げる.イギリスではもともと The Institute of Metals という学会があったが, これがセラミックス学会, ゴム学 会と統合して 1992 年に The Institute of Materials となっ た.この時の会員数は 1 万 9000 名である. 2002 年はこれ がさらに資源採鉱学会と統合し，The Institute of Materials, Minerals and Mining（IOM-3）が設立された.この学会の 会員数は 2 万 4000 名である.イギリスの人口が日本の半 分程度であることを考えると，材料関係の学会としては非 常に大きな会員数であるといえよう.取り扱う活動範囲も， セラミックス, コンポジット, 高分子, ゴム, 軽金属, 鉄 鋼，バイオ，電子，石油などの 17 技術分野にわたり，幅 広い分野で活発な活動がなされている。

ヨーロッパ全体ではさらに積極的な動きがある. 英, 独, 仏が中心となって，ヨーロッパの 24 の学協会が連携して The Federation of European Materials Society という組織が 設立されている。これは，本部を持ち回りとし，2，3 年 ごとに共同の講演大会（EUROMAT）を開催している. EUROMAT2005は, 本年 9 月にチェコのプラハで開催さ れる予定である。

アメリカには，金属関係の TMS と ASM という2つの 主要な学会がある.TMS は学会活動が中心で, 2001 年の レベルで会員数が 9000 名である.一方の ASM は，技術 に注力するとともに, 出版, 講演, 講習に力を注いでおり, 2002 年での会員数 3 万 6000 名である. TMS と ASM は既 に報文集の共同刊行をはじめて扣り，また講演大会に関し ても，セラミックス協会との連携を計る動きがある.

また中国は，金属学会の会員数が 10 万人に達し，この ところ急速にその活動を活発化しつつある. 金属関係の産 業も強くなりつつあり, 将来, 日本の強力なライバルとな るものと予想される。

このような欧米をはじめとする諸外国の金属あるいは材 料関係の学会の動きを見ると, 日本の材料関係の学協会も, 再編などの努力による活性化の取り組みが必要であると思 われる．換言すれば，現行のままでは材料科学分野の ステータスを維持できなくなる恐れがある.

\section{7. 材料戦略委員会の活動}

最後に, 私が主要な活動の場としている金属学会の学協 会連携の試みについて紹介しておく，たまたま私が，2001 年 3 月から 1 年間同学会の会長を務めた時期に, 幾つかの 学協会連携の動さがスタートすることになった。そのうち のひとつは, 欧文誌共同刊行である。2001 年から，金属 
学会の欧文誌 Materials Transactions を他の学会に呼びか けて共同刊行している。参加学協会数は，2001年には 3 学協会であうたが，2005 年には 10 学協会を数えている. この影響もあって，揭載諭文数，総ページ数ともに増える 傾向が続いており，2001 年で論文数 456, ページ数 2654 であったものが，2004 年には論文数 587，ページ数 3362 となっている.

もうひとつは，同じく2001 年の「材料戦略委員会」の 立ち上げである，当初は，この委員会名称は「(金属学会) 材料戦略委員会」であったが, その後, 参加学協会が増え, （金属学会）を外すことが了承された。この委員会では， 材料関係の学協会の連携，産学官連携による政策提言など を目標に扔いて意欲的に活動を行っている，平成 16 年 12 月には，この材料戦略委員会が主体となり，10学協会連 名で「ナノテクノロジー・材料戦略の今後のあり方」につ いての提言をまとめている。この内容は, 総合科学技術会 議の関係者にも紹介されている．またこの活動が引き金に なって, 総合科学技術会議 材料分野研究開発検討会が立 ち上げられ，第 3 期科学技術基本計画に向けた討議が進め られた。

また，この材料戦略委員会が主催し，日本学術会議の後 援を受けて 2005 年 3 月 31 日に材料戦略シンポジゥム「第 3 期科学技術基本計画と材料戦略」が，金属学会春期大会 に合わせて横浜国立大学で開催された。このシンポジゥム では, 総合科学技術会議 森本立男政策企画調査官, 文部
科学省研究振興局 佐藤 透材料開発推進室長, 経済産業 省製造産業局 中山 亨ナノテクノロジー戦略課長, 科学 技術振興機構研究開発戦略センター 村井眞二上席つェロー の講演と材料戦略委員会の岡田益男幹事による提案の紹介 があり活発な討論がなされた。この種の活動が，今後の材 料研究の活性化につながることを期待している.

\section{8.おわりに}

「材料」という分野を表わす用語は，一般には魅力にそ しい言葉と受け止められている。一方で，「ナノテクノロ ジー」というと，多くの方々から「内容は分からないけれ ども，新しそう」という答えが帰ってくる．科学直るいは 工業の分野で新しい取り組みに努めていても，「材料」と いうと古いイメージで捕らえられ，新規提案としてなかな か認知されないのが実情である。この状沉は，同じ材料分 野でも構造材料分野で特に深刻である．材料あるいは材料 科学を社会に認知してもらうには継続的な努力が不可欠で あろう。

このような状況の中で，「材料の学」という新しい学問 分野体系が構築されれば，それは単に材料分野にとどまら ず機械あるいは製造分野に大きなインパクトを与えること になるであろう。.また，日本初の「学」が立ち上がることに なれば，これは分野を越えた派生的な効果をもたらすもの と思われる。この意味で，意欲的な課題に果敢に取り組も うとされている方々のご尽力に期待するところ大である。 